Marquette University

e-Publications@Marquette

Civil and Environmental Engineering Faculty

Civil and Environmental Engineering, Department

Research and Publications

$10-1-2011$

Tertiary-Treated Municipal Wastewater is a Significant Point Source of Antibiotic Resistance Genes Into Duluth-Superior Harbor

Patrick J. McNamara

Marquette University, patrick.mcnamara@marquette.edu

Tucker R. Burch

Timothy M. LaPara

David T. Tan

Mi Yan

See next page for additional authors

Accepted version. Environmental Science \& Technology, Vol. 45, No. 22 (2011): 9543-9549. DOI. (C) 2011 American Chemical Society. Used with permission.

Patrick J. McNamara was affiliated with The University of Minnesota at the time of publication. 
Authors

Patrick J. McNamara, Tucker R. Burch, Timothy M. LaPara, David T. Tan, Mi Yan, and Jessica J. Eichmiller 


\title{
Tertiary-Treated Municipal Wastewater is a Significant Point Source of Antibiotic Resistance Genes into Duluth-Superior Harbor
}

\author{
Timothy M. LaPara* \\ Department of Civil Engineering, University of Minnesota, \\ Minneapolis, $M N$ \\ Tucker R. Burch \\ Department of Civil Engineering, University of Minnesota, \\ Minneapolis, $M N$ \\ Patrick J. McNamara \\ Department of Civil Engineering, University of Minnesota, \\ Minneapolis, $M N$ \\ David T. Tan \\ Department of Civil Engineering, University of Minnesota, \\ Minneapolis, $M N$ \\ Mi Yan \\ Department of Bioproducts and Biosystems Engineering, \\ University of Minnesota,
}

St. Paul, MN

Environmental Science \& Technology, Vol 45, No. 22 (2011): pg. 9543-9549. DOI. This article is (C American Chemical Society and permission has been granted for this version to appear in e-Publications@Marquette. American Chemical Society does not grant permission for this article to be further copied/distributed or hosted elsewhere without the express permission from American Chemical Society. 


\section{Jessica J. Eichmiller \\ Department of Soil, Water, and Climate, University of Minnesota, St. Paul, $M N$}

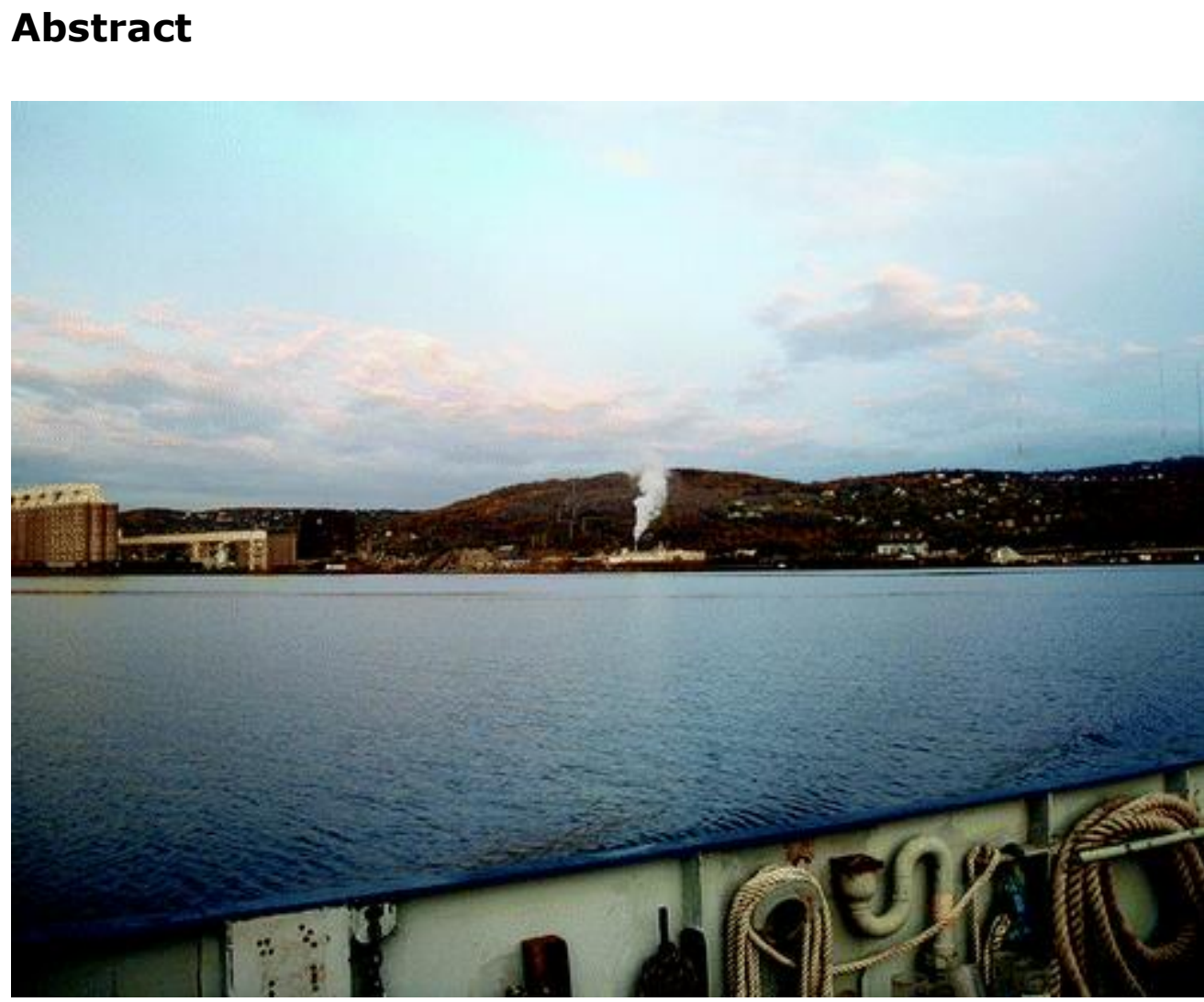

In this study, the impact of tertiary-treated municipal wastewater on the quantity of several antibiotic resistance determinants in Duluth-Superior Harbor was investigated by collecting surface water and sediment samples from 13 locations in Duluth-Superior Harbor, the St. Louis River, and Lake Superior. Quantitative PCR (qPCR) was used to target three different genes encoding resistance to tetracycline $(\operatorname{tet}(\mathrm{A})$, tet $(\mathrm{X})$, and tet $(\mathrm{W}))$, the gene encoding the integrase of class 1 integrons (intI1), and total bacterial abundance (16S rRNA genes) as well as total and human fecal contamination levels (16S rRNA genes specific to the genus Bacteroides). The quantities of tet( $\mathrm{A})$, tet $(\mathrm{X})$, tet $(\mathrm{W})$, intI1, total Bacteroides, and human-specific Bacteroides were typically 20-fold higher in the tertiary-treated wastewater than in nearby surface water samples. In contrast, the quantities of these genes in the St. Louis River and Lake Superior were typically below detection. Analysis of sequences of tet(W) gene fragments from four different samples

Environmental Science \& Technology, Vol 45, No. 22 (2011): pg. 9543-9549. DOI. This article is (C) American Chemical Society and permission has been granted for this version to appear in e-Publications@Marquette. American Chemical Society does not grant permission for this article to be further copied/distributed or hosted elsewhere without the express permission from American Chemical Society. 
NOT THE PUBLISHED VERSION; this is the author's final, peer-reviewed manuscript. The published version may be accessed by following the link in the citation at the bottom of the page.

collected throughout the study site supported the conclusion that tertiarytreated municipal wastewater is a point source of resistance genes into Duluth-Superior Harbor. This study demonstrates that the discharge of exceptionally treated municipal wastewater can have a statistically significant effect on the quantities of antibiotic resistance genes in otherwise pristine surface waters.

\section{Introduction}

Over the past several decades, antibiotic-resistant bacterial infections have become increasingly prevalent, increasing morbidity and mortality as well as the cost of treatment. $\frac{1-3}{1 n}$ response to these clinical concerns, there has been increasing focus on environmental reservoirs of antibiotic resistance over the past several years. ${ }^{4-8}$ Antibiotic use in agriculture, for example, has been heavily scrutinized 9,10 and recently banned in the European Union. In contrast, the role of treated municipal wastewater has received relatively little attention as a reservoir of resistance, in spite of numerous reports suggesting that bacteria resistant to multiple antibiotics $\frac{11-13}{}$ and antibiotic resistance genes $\frac{14-21}{}$ are abundant in municipal wastewater.

Determining the relative importance of treated municipal wastewater as a reservoir of antibiotic resistance is a potentially difficult task. The first challenge is to enumerate "antibiotic resistance" in some meaningful way. Historically, antibiotic resistance would have been quantified by cultivating bacteria based on their phenotypic resistance to a specific antibiotic or set of antibiotics. This approach, however, is insufficient because cultivation-based methods are wellknown to underestimate the quantities and diversity of bacteria. $\underline{22,23}$ The second challenge is to distinguish the impact of treated municipal wastewater from the background level of resistance because antibiotic resistant bacteria and antibiotic resistance genes are natural phenomena ${ }^{5,24}$ and because other human activities (i.e., other than the release of municipal wastewater) have presumably perturbed the majority of surface waters to some extent.

In this study, we examined the impact of tertiary-treated municipal wastewater on the quantities of three tetracycline resistance genes $(\operatorname{tet}(\mathrm{A}), \operatorname{tet}(\mathrm{X})$, and $\operatorname{tet}(\mathrm{W}))$ and the integrase gene of class 1 integrons (intI1) in the St. Louis River, Duluth-Superior Harbor, and Lake Superior. This ecosystem represents an ideal locale for studying

Environmental Science \& Technology, Vol 45, No. 22 (2011): pg. 9543-9549. DOI. This article is (C) American Chemical Society and permission has been granted for this version to appear in e-Publications@Marquette. American Chemical Society does not grant permission for this article to be further copied/distributed or hosted elsewhere without the express permission from American Chemical Society. 
the importance of treated municipal wastewater as a reservoir of antibiotic resistance because the St. Louis River and Lake Superior are surprisingly pristine surface waters with very low background levels of bacteria, $\underline{25}$ which suggests that the levels of antibiotic resistant bacteria also should be very low. Furthermore, the quality of treatment at the Western Lake Superior Sanitary District (WLSSD), which operates the municipal wastewater treatment facility in Duluth, $\mathrm{MN}$, is exemplary. The WLSSD facility treats approximately 40 million gallons of residential, commercial, and industrial wastewater each day via a conventional system consisting of bar screens, grit removal, and a state-of-the-art, high-purity oxygen activated sludge process. The WLSSD wastewater treatment facility, however, is unique in that it further treats the wastewater by passing it through a mixed media filter (consisting of anthracite coal, silica sand, and garnet) before disinfecting (using sodium hypochlorite) the wastewater and discharging it to Duluth-Superior Harbor.

\section{Materials and Methods}

\section{Sample Collection}

Surface water (sample volume $=250 \mathrm{~mL}$ ) and sediment (sample mass $=\sim 0.75 \mathrm{~g}$ wet sediment) samples were collected on October 1, 2010 from the St. Louis River, Duluth-Superior Harbor, and Lake Superior while aboard the R/V Blue Heron (Figure 1). Most of the surface water samples were collected manually at a distance of $0.5 \mathrm{~m}$ below the water surface using sterile polystyrene bottles. A small fraction of the samples (those from Lake Superior) were collected using an SBE 32 Carousel Water Sampler (Sea-Bird Electronics, Inc., Bellevue, WA) at a depth of $5 \mathrm{~m}$ below the water surface. Sediment samples were collected using either a multicorer (Ocean Instruments, San Diego, CA) or a gravity-corer (HTH Teknik; Luleå, Sweden). Sediment samples represent a composite sample of the top $2.5 \mathrm{~cm}$ of sediment. 


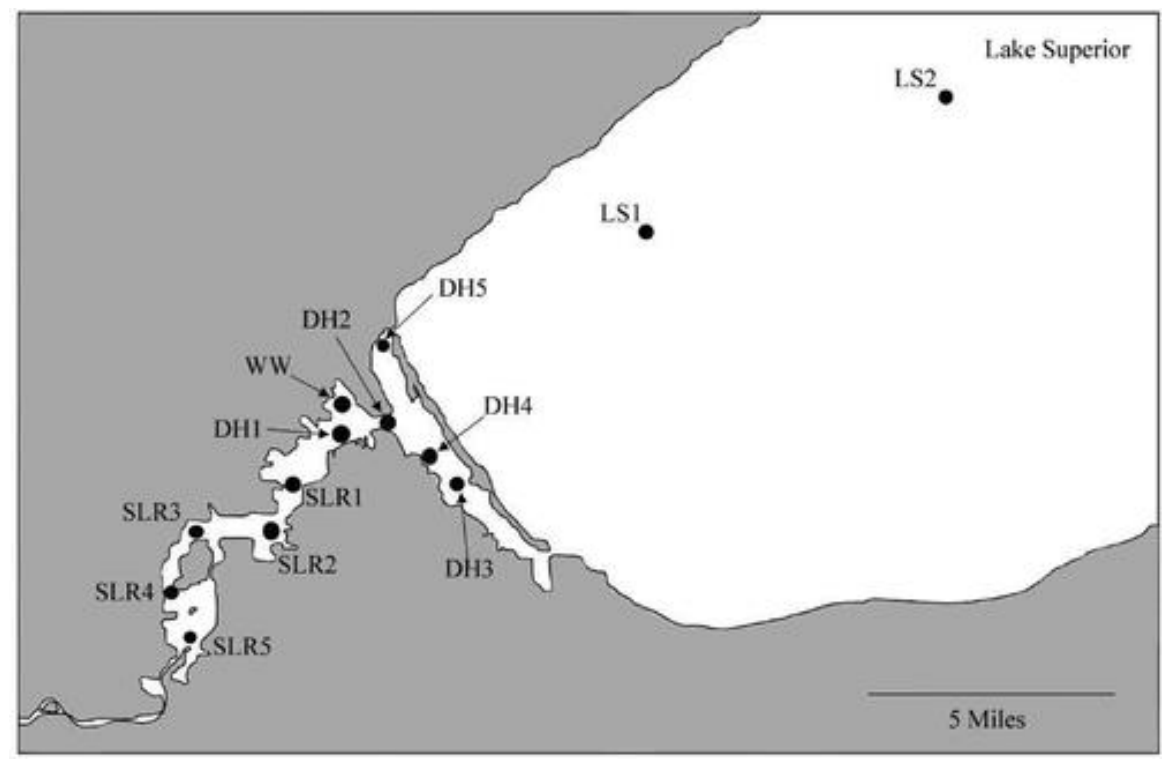

Figure 1. Map of the St. Louis River, Duluth-Superior Harbor, and Lake Superior, identifying the locations from which samples were collected.

As soon as possible after collection (typically less than $30 \mathrm{~min}$; always less than $2 \mathrm{~h}$ ), surface water samples were passed through a $47 \mathrm{~mm}$ diameter nitrocellulose filter (pore size $=0.22 \mu \mathrm{m}$ ) to concentrate microbial biomass. Filters were then immersed in $0.5 \mathrm{~mL}$ of Iysis buffer (120 mM phosphate buffer, $\mathrm{pH}=8.0,5 \%$ sodium dodecyl sulfate) to preserve the sample until genomic DNA could be extracted and purified. All samples were stored on ice while they were transported to the University of Minnesota (within $12 \mathrm{~h}$ ), after which they were stored at $-20^{\circ} \mathrm{C}$ until processed further.

\section{Genomic DNA Extraction}

Water samples (preserved in lysis buffer) underwent three consecutive freeze-thaw cycles and an incubation of $90 \mathrm{~min}$ at $70{ }^{\circ} \mathrm{C}$ to lyse cells. Genomic DNA was then extracted and purified from these samples using the FastDNA Spin Kit (MP Biomedicals, Solon, $\mathrm{OH}$ ) according to manufacturer's instructions. Genomic DNA was also extracted from sediment samples ( $500 \mathrm{mg}$ of wet weight per sample) using a bead beater to lyse cells. Genomic DNA was then extracted and purified from sediment samples using a FastDNA Spin Kit for soil (MP Biomedicals, Solon, $\mathrm{OH}$ ). All genomic DNA extractions were performed in triplicate and stored at $-20^{\circ} \mathrm{C}$ until needed. 
NOT THE PUBLISHED VERSION; this is the author's final, peer-reviewed manuscript. The published version may be accessed by following the link in the citation at the bottom of the page.

\section{Community Analysis}

The composition of the bacterial communities in the aquatic samples was compared by automated ribosomal intergenic spacer analysis (ARISA). The ribosomal intergenic spacer (ITS) regions of Bacteria were amplified using primers ITSF (5'-GTC GTA ACA AGG TAG CCG TA-3') and ITSReub (5'-GCC AAG GCA TCC ACC-3') 26 as described previously. $\underline{27}$ Fragment analysis was performed by denaturing capillary electrophoresis at the Biomedical Genomics Center at the University of Minnesota using an ABI 3130xl Genetic Analyzer (Applied Biosystems, Foster City, CA). The length of the fragments was estimated using the Map Marker 1000 size standard.

\section{Quantitative PCR}

Quantitative real-time PCR ( $q P C R$ ) was used to quantify the presence of three genes encoding tetracycline resistance (tet $(A)$, tet $(\mathrm{W})$, and tet $(\mathrm{X})$ ) and the integrase gene of class 1 integrons (intI1) as described previously. $\frac{15}{}$ These genes were targeted in this study because our prior work demonstrated that these genes were easily detectable in untreated wastewater solids $\frac{15,16}{16}$ and because these genes encode proteins that confer tetracycline resistance via each of the three known mechanisms of resistance. $\frac{28}{\text { QPCR }}$ was also used to quantify the 16S rRNA genes of all members of the domain Bacteria as well as total and human-specific Bacteroides spp. as described previously. $\underline{\underline{29-31}}$

The qPCR analysis was conducted using an Eppendorf Mastercycler ep realplex thermal cycler (Eppendorf, Westbury, NY) or an ABI Prism7000 Sequence Detection System (Applied Biosystems). Each qPCR run consisted of initial denaturation for 10 min at $95^{\circ} \mathrm{C}$, followed by 40 cycles of denaturation at $95^{\circ} \mathrm{C}$ for $15 \mathrm{~s}$, and anneal and extension at $60^{\circ} \mathrm{C}$ (most targets) or at $56^{\circ} \mathrm{C}$ (human-specific Bacteroides) for $1 \mathrm{~min}$. A $25 \mu \mathrm{L}$ reaction mixture contained $12.5 \mu \mathrm{L}$ of iTaq SYBR Green Supermix with ROX (Bio-Rad, Hercules, CA), $25 \mu \mathrm{g}$ bovine serum albumin (Roche Applied Science, Indianapolis, IN), optimized quantities of forward and reverse primers, and a specified volume of template DNA (usually $0.5 \mu \mathrm{L}$ ). The precise volume and concentration of template DNA were empirically optimized for each

Environmental Science \& Technology, Vol 45, No. 22 (2011): pg. 9543-9549. DOI. This article is (C) American Chemical Society and permission has been granted for this version to appear in e-Publications@Marquette. American Chemical Society does not grant permission for this article to be further copied/distributed or hosted elsewhere without the express permission from American Chemical Society. 
sample to generate the lowest detection limit while minimizing inhibition of PCR. Additional information on the qPCR primers, their quantification limits, and their associated products are provided in the Supporting Information.

The quantity of target DNA in unknown samples was calculated based on a standard curve generated using known quantities of template DNA. Standards for qPCR were prepared by PCR amplification of genes from positive controls, followed by ligation into a cloning vector (either the StrataClone PCR kit (Stratagene, Santa Clara, CA) or pGEM-T Easy (Promega, Madison, WI)), and transformation into $E$. coli JM109. Plasmids were purified using the alkaline lysis procedure. $\underline{32}$ Plasmid DNA was quantified by staining with Hoechst 33258 dye and measured on a TD-700 fluorometer (Turner Designs, Sunnyvale, CA) using calf thymus as a DNA standard. Tenfold serial dilutions of plasmid DNA were prepared and run on the thermal cycler to generate standard curves $\left(r^{2}>0.99\right)$. Following qPCR, melting curves were generated and analyzed to verify that nonspecific amplification did not occur.

\section{Clone Libraries}

Fragments of tet(W) genes from four different surface water samples (samples SLR5, DH2, WW, and LS2) were amplified by PCR, purified, ligated into the pGEM-T Easy cloning vector, transformed into Escherichia coli JM109, and plated onto LB agar plates supplemented with $40 \mu \mathrm{g} / \mathrm{mL}$ of ampicillin. This resulted in libraries of tet(W) gene fragments from each of these samples, allowing their nucleotide sequences to be determined. Approximately 30 colonies from each library were randomly picked so that plasmids could be extracted and purified using the alkaline lysis method. Extracted plasmids were then used as template for nucleotide sequence analysis using M13F and M13R as sequencing primers. Bidirectional sequence information was then used to produce a consensus sequence. Approximately $20 \%$ of the plasmids contained primer-dimer rather than a genuine tet(W) gene fragment; these sequences were excluded from further analysis. 
NOT THE PUBLISHED VERSION; this is the author's final, peer-reviewed manuscript. The published version may be accessed by following the link in the citation at the bottom of the page.

\section{Data Analysis}

Nonmetric multidimensional scaling (nMDS) was used on triplicate ARISA profiles to evaluate differences in bacterial community composition based on the presence and intensity of peaks in the electropherograms. The relative intensity of peaks, obtained by dividing the individual intensities by total intensity of all the peaks, was used in the analysis. Peaks falling below $1 \%$ of the total intensity were excluded from the analysis. nMDS was performed using the ade 4 package in $\mathrm{R}$, version 2.4.1. $\underline{33}$

Prior to statistical analysis, samples with gene concentrations below the method detection limit were assigned a value equal to half the detection limit. All gene concentrations were then log-transformed, and this log-transformed data set was used for all subsequent statistical analysis. One-way analysis of variance (ANOVA) was performed with $\mathrm{R}$ version 2.12.0 for all gene targets. An F-test was conducted to determine if results from a specific surface water sample location exhibited gene concentrations that were significantly different from results at the other sample locations. Tukey's honestly significant difference (HSD) test was conducted for each gene target to determine the difference in mean gene concentrations between each possible pair of surface water samples sites. Pearson correlation coefficients of gene concentrations were also calculated using $\mathrm{R}$ version 2.12.0 for all possible pairs of gene targets. The detailed results of all statistical analyses (i.e., $P$ values and/or Pearson correlation coefficients) are provided in the Supporting Information.

All nucleotide sequences were initially compared with sequences in the GenBank database ${ }^{34}$ to verify that the cloned fragments were genuine tet(W) gene fragments. Sequences were then aligned using the ClustalW algorithm $\underline{35}$ using DNAMan version 7.0 software (Lynnon Biosoft, Vaudreuil-Dorion, Quebec, Canada). To avoid artifacts stemming from misamplification during PCR and nucleotide sequencing error, $\underline{36}$ all sequences for which there was not a replicate were excluded from further analysis. 
NOT THE PUBLISHED VERSION; this is the author's final, peer-reviewed manuscript. The published version may be accessed by following the link in the citation at the bottom of the page.

\section{Results}

\section{Bacterial Community Composition}

The composition of the bacterial communities in surface water samples collected along a length of the St. Louis River, DuluthSuperior Harbor, and Lake Superior was assayed by automated ribosomal intergenic spacer analysis (ARISA) (Figure 2 ). The bacterial community composition gradually transitioned along the length of the St. Louis River, into Duluth-Superior Harbor, and out into Lake Superior. In contrast, the composition of bacteria in the treated municipal wastewater from the Western Lake Superior Sanitary District (WLSSD) was significantly different than all of the surface water samples.

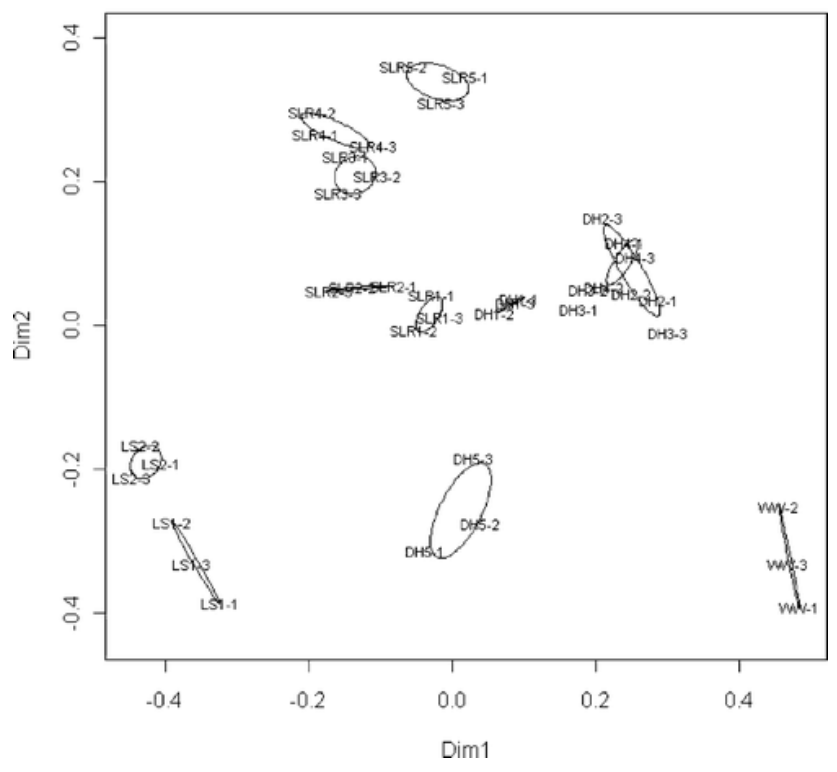

Figure 2. Results of nonmetric multidimensional scaling (nMDS) analysis of bacterial community composition as determined by automated ribosomal intergenic spacer analysis. Ellipses show the $95 \%$ confidence limit of triplicate water samples. Samples were collected from the St. Louis River (identified as "SLR"), Duluth-Superior Harbor (identified as " $\mathrm{DH}^{\prime \prime}$ ), and Lake Superior (identified as "LS"); the precise locations from which samples were collected are shown in Figure $\underline{1}$.

\section{Quantitative PCR}

The amount of bacterial biomass was quantified in the surface water samples by real-time PCR of $16 \mathrm{~S}$ rRNA gene fragments (Figure

Environmental Science \& Technology, Vol 45, No. 22 (2011): pg. 9543-9549. DOI. This article is (C) American Chemical Society and permission has been granted for this version to appear in e-Publications@Marquette. American Chemical Society does not grant permission for this article to be further copied/distributed or hosted elsewhere without the express permission from American Chemical Society. 
3). Bacterial biomass in the different surface water samples varied substantially from as high as $3.6 \times 10^{6}$ gene copies per $\mathrm{mL}$ (sample location $=$ SLR2) to as low as $2.1 \times 10^{5}$ gene copies per $\mathrm{mL}$ (sample location $=$ LS2). These quantifications of 16S rRNA gene copies are substantially lower than that previously reported from the Haihe River in China $\left(10^{8}-10^{9} \text { copies per } \mathrm{mL}\right)^{37}$ and from a drinking water source in Michigan $\left(3.4 \times 10^{9}\right.$ copies per $\left.\mathrm{mL}\right), 38$ but are consistent with previously reported direct cell counts from Lake Superior $\left(1 \times 10^{5}\right.$ cells $/ \mathrm{mL}) . \underline{25}$ The quantity of bacterial biomass in the treated WLSSD effluent was $5.4 \times 10^{6}$ gene copies per $\mathrm{mL}$, which was higher than any surface water sample.

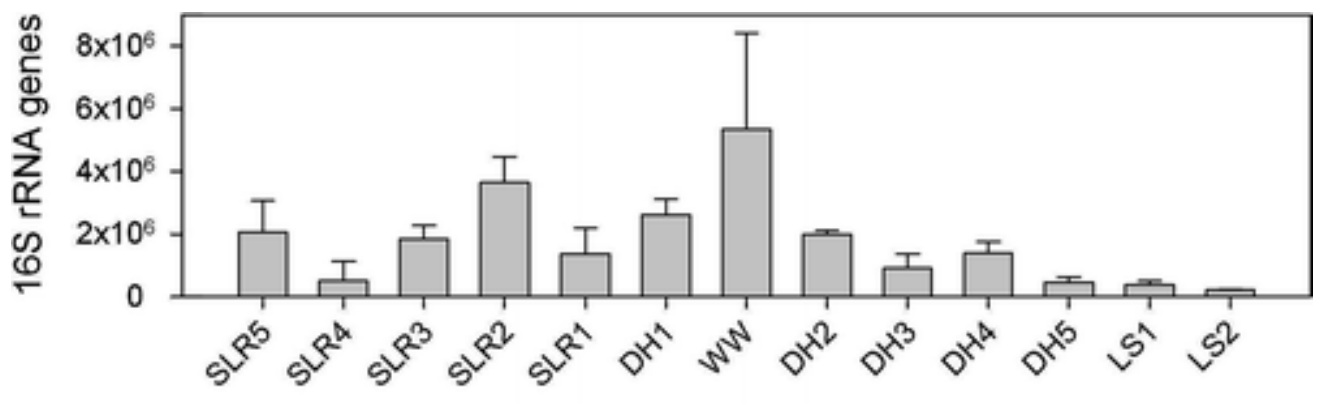

Sample Location

Figure 3. Quantities (gene copies per $\mathrm{mL}$ ) of $16 \mathrm{~S}$ rRNA genes in water samples collected from the St. Louis River, Duluth-Superior Harbor, the outfall from the Western Lake Superior Sanitary District, and Lake Superior. Values shown are the arithmetic means; error bars show the standard deviation of the mean. The locations from which samples were collected are shown in Figure 1 .

The quantities of three different genes that encode resistance to tetracycline $(\operatorname{tet}(\mathrm{A})$, tet $(\mathrm{X})$, and $\operatorname{tet}(\mathrm{W}))$ as well as the quantity of the integrase gene (intI1) of class 1 integrons were also determined along the St. Louis River, in Duluth-Superior Harbor, and in Lake Superior (Figure 4 ; for the same data normalized to 16S rRNA genes, see Supporting Information). The quantities of $\operatorname{tet}(\mathrm{A})$ and $\operatorname{tet}(\mathrm{X})$ followed similar patterns in the aquatic samples; both of these genes were at relatively high concentrations in the WLSSD effluent $\left(\operatorname{tet}(\mathrm{A}): 6.3 \times 10^{2}\right.$ copies per $\mathrm{mL}$; tet $(\mathrm{X}): 1.2 \times 10^{3}$ copies per $\mathrm{mL}$ ), slightly above the detection limit at several locations within Duluth-Superior Harbor, and below the detection limit in the St. Louis River and in Lake Superior. The pattern of intI1 genes was somewhat similar to that observed with tet $(\mathrm{A})$ and tet $(\mathrm{X})$, except that a more distinct hump-shaped profile, albeit slightly skewed into Duluth-Superior Harbor, was observed; this 
hump-shaped profile began in the St. Louis River and encompassed all but one sample collected from Duluth-Superior Harbor. An entirely different profile was observed with respect to the quantity of tet(W) genes, which were quantifiable in every aquatic sample with only the WLSSD effluent $\left(1.8 \times 10^{4}\right.$ gene copies per $\left.\mathrm{mL}\right)$ and one sample from Duluth-Superior Harbor (sample DH4: $5.3 \times 10^{3}$ gene copies per $\mathrm{mL}$ ) being statistically greater $(P<0.05)$ than the other samples. Because the quantities of $16 \mathrm{~S}$ rRNA genes were relatively constant among the different water samples (i.e., within an order of magnitude), the quantities of tet $(\mathrm{A})$, tet $(\mathrm{X})$, tet $(\mathrm{W})$, and intI1 normalized to $16 \mathrm{~S}$ rRNA genes follow similar patterns to those described above (see Supporting Information for more details).

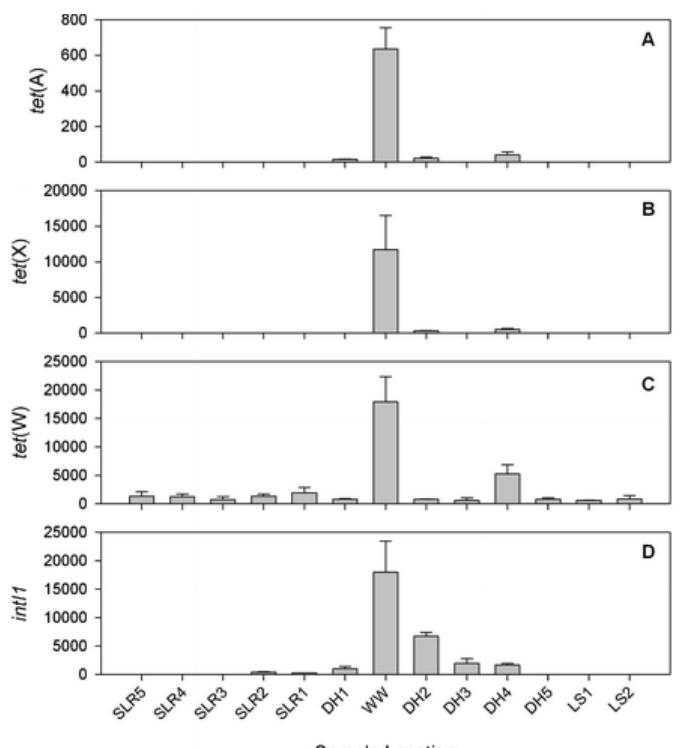

Figure 4. Quantities (gene copies per $m L$ of water) of tet( $A)$, tet $(W)$, tet $(X)$, and the integrase gene of class 1 integrons (intI1) in samples collected from the St. Louis River, Duluth-Superior Harbor, the outfall from the Western Lake Superior Sanitary District, and Lake Superior. Values shown are the arithmetic means; error bars show the standard deviation of the mean. The locations from which samples were collected are shown in Figure $\underline{1}$.

The quantities of $16 \mathrm{~S}$ rRNA genes from all Bacteroides spp. in the aquatic samples followed a trend similar to that observed with the tet $(\mathrm{W})$ quantities (Figure $\underline{5} \mathrm{~A})$. The highest quantity of Bacteroides spp. was found in the WLSSD effluent $\left(6.8 \times 10^{3}\right.$ gene copies per $\left.\mathrm{mL}\right)$, but otherwise most of the samples had relatively low concentrations that were similar. In contrast, the quantities of human-specific Bacteriodes spp. followed a trend like that of $\operatorname{tet}(\mathrm{A})$ and $\operatorname{tet}(\mathrm{X})$, in which a 
relatively high concentration was detected in the WLSSD effluent (1.0 $\times 10^{2}$ gene copies per $\mathrm{mL}$ ); two samples from Duluth-Superior Harbor had quantities slightly higher than the detection limit, but then all other samples were below the detection limit.

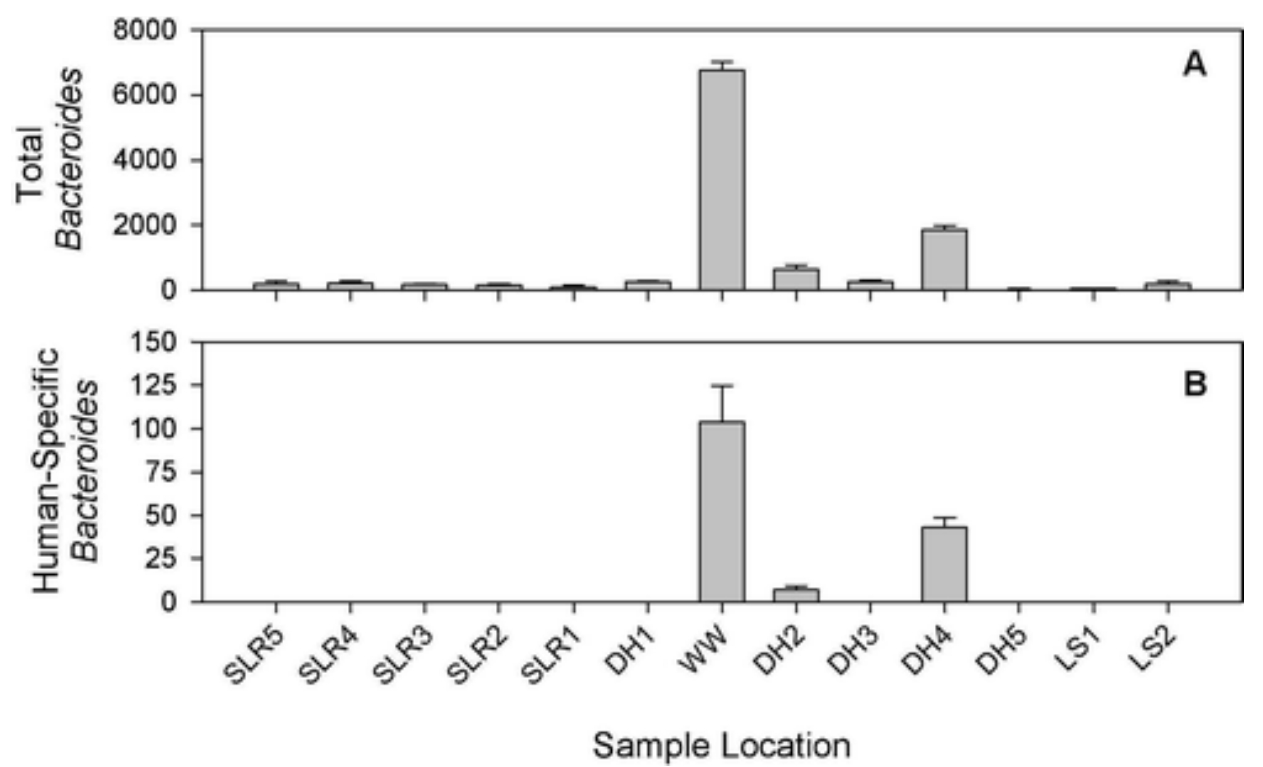

Figure 5. Quantities (gene copies per $\mathrm{mL}$ of water) of $16 \mathrm{~S}$ rRNA genes from all Bacteriodes spp. and from human-specific Bacteroides spp. in water samples collected from the St. Louis River, Duluth-Superior Harbor, the outfall from the Western Lake Superior Sanitary District, and Lake Superior. Values shown are the arithmetic means; error bars show the standard deviation of the mean. The locations from which samples were collected are shown in Figure $\underline{1}$.

Four sediment samples were also collected from Duluth-Superior Harbor and Lake Superior (Table 1 ). Each of these samples had similar concentrations of total bacteria, as measured by qPCR of $16 \mathrm{~S}$ rRNA genes. The quantities of the other genetic markers tracked in this study, however, varied significantly depending on sample location (except for human-specific Bacteroides spp., which were not detected in any of the sediment samples). The highest concentrations of these genetic markers were detected in sediment samples collected from near the WLSSD outfall (samples WW and DH1) compared to the samples collected from the Duluth-Superior Harbor channel (sample DH3) and from Lake Superior (sample LS2). 
Table 1. Arithmetic Means (Units = gene copies per wet gram of sediment; $n$ = 3) of Various Genes Detected in Sediment Samples Collected near the WLSSD Outfall, from Duluth-Superior Harbor, and from Lake Superior (See Figure 1 for Actual Locations) $\underline{\text { a }}$

\begin{tabular}{|c|c|c|c|c|c|c|}
\hline $\begin{array}{c}\text { sample } \\
\text { location }\end{array}$ & $\begin{array}{c}\text { all 16S } \\
\text { rRNA }\end{array}$ & $\begin{array}{c}\text { all } \\
\text { Bacteroides } \\
\text { spp. }\end{array}$ & $\operatorname{tet}(\mathrm{A})$ & $\operatorname{tet}(\mathrm{X})$ & $\operatorname{tet}(\mathrm{W})$ & intI 1 \\
\hline WW & $\begin{array}{l}1.9 \times \\
10^{10}(6.5 \times \\
\left.10^{9}\right)\end{array}$ & $\begin{array}{l}6.9 \times 10^{4}(3.9 \times \\
\left.10^{4}\right)\end{array}$ & $\begin{array}{l}2.1 \times \\
10^{6}(6.8 \times \\
\left.10^{5}\right)\end{array}$ & $\begin{array}{l}2.9 \times \\
10^{4}(5.4 \times \\
\left.10^{3}\right)\end{array}$ & $\begin{array}{l}1.9 \times \\
10^{4}(9.3 \times \\
\left.10^{3}\right)\end{array}$ & $\begin{array}{l}2.4 \times \\
10^{6}(6.6 \times \\
\left.10^{5}\right)\end{array}$ \\
\hline DH1 & $\begin{array}{l}2.1 \times \\
10^{10}(5.1 \times \\
\left.10^{9}\right)\end{array}$ & $\begin{array}{l}2.3 \times 10^{5}(1.4 \times \\
\left.10^{5}\right)\end{array}$ & $\begin{array}{l}7.4 \times \\
10^{5}(1.9 \times \\
\left.10^{5}\right)\end{array}$ & $\begin{array}{l}1.2 \times \\
10^{4}(2.3 \times \\
\left.10^{3}\right)\end{array}$ & $\begin{array}{l}6.5 \times \\
10^{4}(3.7 \times \\
\left.10^{4}\right)\end{array}$ & $\begin{array}{l}2.5 \times \\
10^{6}(5.5 \times \\
\left.10^{5}\right)\end{array}$ \\
\hline DH3 & $\begin{array}{l}1.7 \times \\
10^{10}(5.1 \times \\
\left.10^{8}\right)\end{array}$ & $\begin{array}{l}4.9 \times 10^{4}(2.8 \times \\
\left.10^{4}\right)\end{array}$ & $\begin{array}{l}3.7 \times \\
10^{5}(6.8 \times \\
\left.10^{4}\right)\end{array}$ & b.d. $\underline{b}$ & $\begin{array}{l}2.6 \times \\
10^{4}(1.4 \times \\
\left.10^{4}\right)\end{array}$ & $\begin{array}{l}7.7 \times \\
10^{5}(4.3 \times \\
\left.10^{4}\right)\end{array}$ \\
\hline LS2 & $\begin{array}{l}1.9 \times \\
10^{10}(5.7 \times \\
\left.10^{9}\right)\end{array}$ & $\begin{array}{l}2.3 \times 10^{4}(3.2 \times \\
\left.10^{3}\right)\end{array}$ & $\begin{array}{l}1.2 \times \\
10^{5}(1.2 \times \\
\left.10^{4}\right)\end{array}$ & b.d. & $\begin{array}{l}1.1 \times \\
10^{4}(4.1 \times \\
\left.10^{3}\right)\end{array}$ & $\begin{array}{l}4.9 \times \\
10^{5}(8.7 \times \\
\left.10^{4}\right)\end{array}$ \\
\hline
\end{tabular}

aHuman-specific Bacteroides spp. were also targeted by real-time PCR, but were below the quantification limit in all four sample locations. The numbers in parentheses represent the standard deviation of the mean.

bb.d., below detection.

\section{PCR Cloning of tet(W) Gene Fragments}

In a previous study, tet(W) gene sequences corresponded to the location from which they originated (i.e., from agriculture, from municipal wastewater, etc.). $\underline{39}$ Nucleotide sequences, therefore, were determined from four different clone libraries (from samples SLR5, WW, DH2, and LS2) of tet(W) gene fragments to determine whether or not the type of tet(W) genes varied in the St. Louis River, DuluthSuperior Harbor, and Lake Superior. Comparing only nucleotide sequences for which a matching nucleotide sequence was detected (i.e., singletons were excluded from consideration), only two distinct clones were detected. The first of these clone types (100\% sequence identity to GenBank accession no. GU116971) comprised $100 \%$ of the clone library from the St. Louis River sample (sample = SLR5; $n=$ 17), slightly less than half of the clone library from the DuluthSuperior Harbor sample (sample $=\mathrm{DH} 2 ; 8$ out of 17 clones), and the majority of the clones from the Lake Superior sample (sample $=$ LS2; 17 out of 20 clones). In contrast, the second clone type (100\% sequence identity to GenBank accession no. AP012212) represented $100 \%$ of the library from the sample collected from the tertiarytreated wastewater (sample $=\mathrm{WW} ; n=14$ ), slightly more than half of 
the Duluth-Superior Harbor clone library (9 out of 17 clones), and a small fraction of the LS2 library (3 out of 20 clones).

\section{Discussion}

The importance of municipal wastewater treatment as a necessary component of modern society is without question. $\underline{40,41}$ The primary goal of municipal wastewater treatment is to protect surface water quality from the adverse effects of the relatively high concentration of nutrients (biodegradable carbon, nitrogen, and phosphorus) in the sewage; the secondary goal of municipal wastewater treatment is to protect public health from direct exposure to pathogens (usually via accidental ingestion of surface water). $\frac{41}{}$ An unintended consequence of municipal wastewater treatment, however, is the creation of a centralized location where bacteria from the microflora of healthy and unhealthy humans coalesce. Municipal wastewater and municipal wastewater treatment, therefore, simultaneously represent a pertinent reservoir of resistance and a potential opportunity to ameliorate this reservoir of resistance, respectively.

The present study demonstrates that treated municipal wastewater is a statistically significant point source of three tetracycline resistance determinants as well as the integrase gene of class 1 integrons into Duluth-Superior Harbor. The tertiary-treated wastewater had approximately 20 -fold higher concentrations of various antibiotic resistance determinants than the local background levels in the St. Louis River and Lake Superior. Furthermore, the concentrations of antibiotic resistance genes generally correlated to either all Bacteroides spp. (a measure of total fecal material) or human-specific Bacteroides spp. (a measure of human-generated fecal material) (see Supporting Information for more details). Finally, the sequence of tet $(\mathrm{W})$ gene fragments in tertiary-treated wastewater was unique compared to that compared to that found in the St. Louis River and Lake Superior, again suggesting that the tertiary-treated municipal wastewater was a significant source of antibiotic resistant determinants into Duluth-Superior Harbor - where approximately equal amounts of these two gene sequences were detected. 
NOT THE PUBLISHED VERSION; this is the author's final, peer-reviewed manuscript. The published version may be accessed by following the link in the citation at the bottom of the page.

The present study is unique and novel because of its ability to clearly identify tertiary-treated municipal wastewater as a point source of antibiotic resistance genes, which have been identified as an emerging pollutant of concern. $\underline{42}$ Previous studies in which treated municipal wastewater was implicated as a source of antibiotic resistance determinants were substantially more convoluted because multiple sources of antibiotic resistance genes existed, such as agricultural activity and industrial wastewater discharges. $\frac{39,43}{}$ In contrast, the current study is considerably more straightforward to interpret because of the general transition from pristine (St. Louis River) to relatively perturbed (Duluth-Superior Harbor) back to pristine (Lake Superior), with virtually no known anthropogenic sources of antibiotic resistance genes other than a large input of tertiary-treated municipal wastewater from WLSSD (flow rate $=40$ million gallons per day) and a small input of secondary-treated municipal wastewater from Superior, Wisconsin (flow rate $=5$ million gallons per day; near sample location DH4).

In conclusion, municipal wastewater treatment operations need to be more carefully considered as an important factor in the global ecology of antibiotic resistance. Municipal wastewater contains numerous types of waste, of which human fecal material is known to have substantial concentrations of both antibiotic resistant bacteria and antibiotic resistance genes. $\frac{44}{}$ Municipal wastewater treatment operations undoubtedly remove a very large fraction of the antibiotic resistance genes in untreated sewage prior to discharging the treated effluent. This study demonstrates that even tertiary-treated municipal wastewater is a statistically significant source of antibiotic resistance genes in otherwise pristine surface waters; additional research is needed to determine the importance of treated municipal wastewater in the overall proliferation of antibiotic resistance.

\section{Acknowledgment}

This work was supported by the National Science Foundation (CBET-0967176) and by the Minnesota Environment and Natural Resources Trust Fund (for ship time on the R/V Blue Heron). The majority of this work was performed during the laboratory portion of CE 8551: Environmental MicrobiologyMolecular Theory and Methods during the Fall 2010 semester at the University of Minnesota. 
The assistance of the crew of the R/V Blue Heron is gratefully acknowledged. Dan Engstrom, Bill Arnold, Cale Anger, Noah Hensley, and Hao Pang are also gratefully acknowledged for their assistance with the collection and processing of sediment samples.

\section{Supporting Information}

Information regarding the qPCR primers and conditions (Table S1) and statistical analyses (Tables S2-S10). Additional results are also included regarding tetracycline resistance and intI1 genes normalized to $16 \mathrm{~S}$ rRNA genes (Figure S1). This material is available free of charge via the Internet at http://pubs.acs.org.

\section{References}

1 Andersson, D. I.; Hughes, D.Antibiotic resistance and its cost: is it possible to reverse resistance? Nat. Rev. Microbiol. 2010, 8, 260- 271

2 Levy, S. B. The antibiotic paradox: How miracle drugs are destroying the miracle; Plenum Press: New York, 1992.

3 Levy, S. B.Antibiotic resistance: Consequences of inaction Clin. Infect. Dis. 2001, 33, S124- S129

${ }^{4}$ Alonso, A.; Sánchez, P.; Martínez, J. L.Environmental selection of antibiotic resistance genes Environ. Microbiol. 2001, 3, 1- 9

${ }^{5}$ Allen, H. K.; Donato, J.; Wuimi Wang, H.; Cloud-Hansen, K. A. ; Davies, J.; Handelsman, J.Call of the wild: Antibiotic resistance genes in natural environments Nat. Rev. Microbiol. 2010, 8, 251- 259

${ }^{6}$ Canton, R.Antibiotic resistance genes from the environment: a perspective through newly identified antibiotic resistance mechanisms in the clinical setting Clin. Microbiol. Infect. 2009, 15, 20- 25

ID'Costa, V. M.; Griffiths, E.; Wright, G. D.Expanding the soil antibiotic resistome: exploring environmental diversity Curr. Opin. Microbiol. $2007,10,481-489$

8 Martínez, J.Antibiotics and antibiotic resistance genes in natural environments Science 2008, 321, 365- 367

9 Lipsitch, M.; Singer, R. S.; Levin, B. R.Antibiotics in agriculture: when is it time to close the barn door? Proc. Natl. Acad. Sci. U.S.A. 2002, 99, $5752-5754$

10 Smith, D. L.; Dushoff, J.; Morris, J. G., Jr.Agricultural antibiotics and human health PLoS Med. 2005, 2, 731- 735

11Merlin, C.; Bonot, S.; Courtois, S.; Block, J.-C.Persistence and dissemination of the multiple-antibiotic-resistance plasmid pB10 in the microbial communities of wastewater sludge microcosms Water Res. 2011, 45, 2897- 2905

Environmental Science \& Technology, Vol 45, No. 22 (2011): pg. 9543-9549. DOI. This article is @ American Chemical Society and permission has been granted for this version to appear in e-Publications@Marquette. American Chemical Society does not grant permission for this article to be further copied/distributed or hosted elsewhere without the express permission from American Chemical Society. 
NOT THE PUBLISHED VERSION; this is the author's final, peer-reviewed manuscript. The published version may be accessed by following the link in the citation at the bottom of the page.

12Novo, A.; Manaia, C. M.Factors influencing antibiotic resistance burden in municipal wastewater treatment plants Appl. Microbiol. Biotechnol. 2010, 87, 1157- 1166

13 Ramsden, S. J.; Ghosh, S.; Bohl, L. J.; LaPara, T. M.Phenotypic and genotypic analysis of bacteria isolated from three municipal wastewater treatment plants on tetracycline-amended and ciprofloxacin-amended growth media J. Appl. Microbiol. 2010, 109, 1609- 1618

${ }^{14}$ Auerbach, E. A.; Seyfried, E. E.; McMahon, K. D.Tetracycline resistance genes in activated sludge wastewater treatment plants Water Res. 2007, 41, 1143- 1151

15 Diehl, D. L.; LaPara, T. M.Effect of temperature on the fate of genes encoding tetracycline resistance and the integrase of class 1 integrons within anaerobic and aerobic digesters treating municipal wastewater solids Environ. Sci. Technol. 2010, 44, 9128- 9133

${ }^{16}$ Ghosh, S.; Ramsden, S. J.; LaPara, T. M.The role of anaerobic digestion in controlling the release of tetracycline resistance genes and class 1 integrons from municipal wastewater treatment plants Appl. Microbiol. Biotechnol. 2009, 84, 791- 796

17Moura, A.; Henriques, I.; Smalla, K.; Correia, A.Wastewater bacterial communities bring together broad-host range plasmids, integrons and a wide diversity of uncharacterized gene cassettes Res. Microbiol. 2010, 161, 58- 66

18 Munir, M.; Wong, K.; Xagoraraki, I.Release of antibiotic resistant bacteria and genes in the effluent and biosolids of five wastewater utilities in Michigan Water Res. 2011, 45, 681- 693

19 Zhang, T.; Zhang, M.; Zhang, X.; Fang, H. H. P.Tetracycline resistance genes and tetracycline resistant lactose-fermenting Enterobacteriaceae in activated sludge of sewage treatment plants Environ. Sci. Technol. $2009,43,3455-3460$

20Zhang, X.; Zhang, T.; Zhang, M.; Fang, H. H. P; Cheng, S.P.Characterization and quantification of class 1 integrons and associated gene cassettes in sewage treatment plants Appl. Microbiol. Biotechnol. 2009, 82, 1169- 1177

21Zhang, X.-X.; Zhang, T.Occurrence, abundance, and diversity of tetracycline resistance genes in 15 sewage treatment plants across China and other global locations Environ. Sci. Technol. 2011, 45, 2598- 2604

22Amann, R. I.; Ludwig, W.; Schleifer, K. H.Phylogenetic identification and in situ detection of individual microbial cells without cultivation Microbiol. Rev. 1995, 59, 143- 169

23Staley, J. T.; Konopka, A. Measurement of in situ activities of nonphotosynthetic microorganisms in aquatic and terrestrial habitats Annu. Rev. Microbiol. 1985, 39, 321- 346

Environmental Science \& Technology, Vol 45, No. 22 (2011): pg. 9543-9549. DOI. This article is (C American Chemical Society and permission has been granted for this version to appear in e-Publications@Marquette. American Chemical Society does not grant permission for this article to be further copied/distributed or hosted elsewhere without the express permission from American Chemical Society. 
NOT THE PUBLISHED VERSION; this is the author's final, peer-reviewed manuscript. The published version may be accessed by following the link in the citation at the bottom of the page.

24Davies, J.; Davies, D.Origins and evolution of antibiotic resistance Microbiol. Mol. Biol. Rev. 2010, 74, 417- 433

${ }^{25}$ Cotner, J. B.; Ogdahl, M. L.; Biddanda, B. A.Double-stranded DNA measurement in lakes with the fluorescent stain PicoGreen and the application to bacterial bioassays Aquat. Microb. Ecol. 2001, 25, 6574

${ }^{26}$ Cardinale, M.; Brusetti, L.; Quatrinia, P.; Borin, S.; Puglia, A.; Rizzi, A.; Zanardini, E.; Sorlini, C.; Corselli, C.; Daffonchio, D.Comparison of different primer sets for use in automated ribosomal intergenic spacer analysis of complex bacterial communities Appl. Environ. Microbiol. 2004, 70, 6147- 6156

${ }^{27}$ Nelson, D. K.; LaPara, T. M.; Novak, P. J.Effects of ethanol-based fuel contamination: Microbial community changes, production of regulated compounds, and methane generation Environ. Sci. Technol. 2010, 44, $4525-4530$

${ }^{28}$ Chopra, I.; Roberts, M. 2001. Tetracycline antibiotics: mode of action, applications, molecular biology, and epidemiology of bacterial resistance. Microbiol. Mol. Biol. Rev. 2001, 65, 232- 260.

${ }^{29}$ Berhardt, A. E.; Field, K. G. 2000. Identification of nonpoint sources of fecal pollution in coastal waters by using host-specific $16 \mathrm{~S}$ ribosomal DNA genetic markers from fecal anaerobes. Appl. Environ. Microbiol. 2000, $66,1587-1594$

30 Berhardt, A. E.; Field, K. G.A PCR assay to discriminate human and ruminant feces on the basis of host differences in BacteroidesPrevotella genes encoding 16S rRNA Appl. Environ. Microbiol. 2000, $66,4571-4574$

313eurinck, S.; Defiordt, T.; Verstraete, W.; Siciliano, S. D.Detection and quantification of the human-specific HF183 Bacteroides 16S rRNA genetic marker with real-time PCR for assessment of human faecal pollution in freshwater Environ. Microbiol. 2005, 7, 249- 259

32Sambrook, J.; Fritsch, E. F.; Maniatis, T. Molecular Cloning: A laboratory manual, 2nd ed.; Cold Spring Harbor Laboratory: Cold Spring Harbor, NY, 1989.

33 Thioulouse, J.; Chessel, D.; Dolédec, S.; Olivier, J. M.Ade-4: a multivariate analysis and graphical display software Stat. Comput. 1997, 7, 75- 83

34Benson, D. A.; Karsch-Mizrachi, I.; Lipman, D. J.; Ostell, J.; Rapp, B. A. ; Wheeler, D. L.GenBank Nucleic Acids Res. 2002, 30, 17- 20

35Thompson, J. D.; Higgins, D. G.; Gibson, T. J.CLUSTAL W: improving the sensitivity of progressive multiple sequence alignment through sequence weighting, position-specific gap penalties and weight matrix choice Nucleic Acids Res. 1994, 22, 4673- 4680 
NOT THE PUBLISHED VERSION; this is the author's final, peer-reviewed manuscript. The published version may be accessed by following the link in the citation at the bottom of the page.

${ }^{36}$ Ling, L. L.; Keohavong, P.; Dias, C.; Thilly, W. G.Optimization of the polymerase chain reaction with regard to fidelity: modified T7, Taq, and vent DNA polymerases PCR Methods Appl. 1991, 1, 63- 69

37Yi, L.; Daqing, M.; Rysz, M.; Qixing, Z.; Hongjie, Z.; Lin, X.; Alvarez, P. J. J.Trends in antibiotic resistance genes occurrence in the Haihe River, China Environ. Sci. Technol. 2010, 44, 7220- 7225

38Xi, C.; Zhang, Y.; Marrs, C. F.; Ye, W.; Simon, C.; Foxman, B.; Nriagu, J.Prevalence of antibiotic resistance in drinking water treatment and distribution systems Appl. Environ. Microbiol. 2009, 75, 5714- 5718

${ }^{39}$ Storteboom, H. ; Arabi, M.; Davis, J. G; Crimi, B.; Pruden, A.Tracking antibiotic resistance genes in the South Platte River basin using molecular signatures of urban, agricultural, and pristine sources Environ. Sci. Technol. 2010, 44, 7397- 7404

${ }^{40}$ Arthurson, V.Proper sanitization of sewage sludge: a critical issue for a sustainable society Appl. Environ. Microbiol. 2008, 74, 5267- 5275

41 Tchobanoglous, G.; Burton, F. L.; Stensel, H. D. Wastewater engineering: Treatment and Reuse, 4th ed.; Metcalf and Eddy, Inc., McGraw-Hill: Boston, MA, 2003.

42Pruden, A.; Pei, R.; Storteboom, H.; Carlson, K. H.Antibiotic resistance genes as emerging contaminants: studies in northern Colorado Environ. Sci. Technol. 2006, 40, 7445- 7450

${ }^{43}$ Graham, D. W.; Olivares-Rieumont, S.; Knapp, C. W.; Lima, L.; Werner, D. ; Bowen, E.Antibiotic resistance gene abundances associated with waste discharges to the Almendares River near Havana, Cuba Environ. Sci. Technol. 2011, 45, 418-424

44 Sommer, M. O. A.; Dantas, G.; Church, G. M.Functional characterization of the antibiotic resistance reservoir in the human microflora Science 2009, 325, 1128- 1131

*Tel.: (612) 624-6028. Fax: (612) 626-7750. E-mail: lapar001@umn.edu. Society does not grant permission for this article to be further copied/distributed or hosted elsewhere without the express permission from American Chemical Society. 